\title{
Information and Communication Technology Skills of Students Using the Distant Education Management System to Complete Their Theology Undergraduate Education
}

\author{
Murat Yalman ${ }^{1}$, Bulent Basaran ${ }^{1}$, Selehattin Gonen ${ }^{2}$ \\ ${ }^{1}$ Computer Education and Instructional Technology Dicle University, Turkey \\ ${ }^{2}$ Department of Physics Education, Dicle University, Turkey \\ Correspondence: Murat Yalman, Computer Education and Instructional Technology Dicle University, Turkey.
}

Received: July 19, 2016 Accepted: August 3, 2016 Online Published: August 19, 2016

doi:10.11114/jets.v4i10.1752 URL: http://dx.doi.org/10.11114/jets.v4i10.1752

\begin{abstract}
Considering several variables, the present study aimed at examining the information and communication technology skills of university students taking their courses with the distant education system. In the study, the singular and relational survey model, one of general survey models, was used. The research sample was made up of 381 students attending the Distant Undergraduate Education Completion Program in Theology (DUECPT) at Dicle University in the Diyarbakir in Turkey in the academic year of 2013-2014. The first part of the questionnaire used the data collection tool in the study covered such demographic information about the students to reveal personal information about them as well as their use of information and communication technologies. As for the second part of the questionnaire, it included a scale to determine the participants' information and technology skills. In the study, such descriptive statistics as frequencies, percentages, mean scores, mod and median as well as such parametric tests as $t$-test and one-way analysis of variance were applied. The results revealed that the university students' information and communication technology skills differed significantly with respect to their gender, Internet use time, years of experience in computer use and their preferences of mobile device and that there was no significant difference with respect to their preferences of instructional methods (face-to-face or blended), their foreign language proficiencies, their preferences for studying (as a group or individual) and their preferences in learning.
\end{abstract}

Keywords: Information and communication technologies, skills, attitudes, university students

\section{Introduction}

In modern societies, although there is a gradual increase in the number of studies on Information and Communication Technologies (ICT), many related studies demonstrated great differences between individuals' levels of ICT use skills and the frequency of their use of ICTs (Verhoeven et. al., 2014). Most of these studies tried to reveal these differences putting forward such causes as gender, age, educational background, access to ICTs, family culture, wealth, computer-related anxiety, belief in the benefits of the computer and rural and urban fields (Wang et al., 2009; Carlsson et al., 2006; Chatzoglou et al., 2009; Cho et al., 2009; Lee, 2008; Lee, 2010; Lee et al., 2009; Teo et al., 2009; Hargittai, 2010; Salajan et al., 2010; Kutluca, 2010). The results obtained in a number of studies conducted with higher education students differ due to the factors of place and time. Depending on the fact that no significant difference was found in studies between undergraduate freshman and senior students (Kaminski et al., 2009) or between freshman and fifth-grade medicine faculty students (Strømsø et al. 2004) in terms of their ICT usages, it could be stated that their capacity of ICT use does not increase in time.

Knowledge of Information and communication technologies and related skills play an important role in today's educational activities. Studies revealed that due to the widespread use of information and communication technologies especially in higher education, university students generally have higher levels of related skills (Yalman \& Tunga, 2014). Taking into account the conditions that require individuals from different professions to use technology, professional knowledge that students acquire in technology-aided courses becomes increasingly important. The importance of technology integration into higher education courses can be better understood considering such situations as a doctor's use of advanced technological tools for diagnosis or treatment, an architect's use of different computer 
programs for drawing, a teacher's use of technology to prepare instructional materials and a banker's use of different programs for calculations. In addition, with the integration of technology into courses, it is now more important for faculty members to become technology literate instructors. Also, when the need for technology-literate individuals due to the FATIH Project in education is considered, technology-integrated courses are inevitably necessary today. Individuals using information and communication technologies are likely to have different levels of related knowledge and views. Thus, it is important for them to acquire and develop certain skills so that they can make better use of these technologies (Peter and Valkenburg 2006; Van Dijk 2006). Individuals' use of the Internet and computer or their level of knowledge about such technological tools could help develop their related skills.

It is important to teach and apply information and communication technologies in secondary schools as well as in high schools. Studies revealed a positive relationship between ICT use and related skills in elementary and secondary schools in the fields of science and mathematics and a negative relationship in social fields and in other fields (Firat \& Özden, 2013). In addition, studies conducted regarding ICT use in elementary schools reported a development in students' thinking skills (McMahon, 2009). In one study carried out by McMahon (2009) with ninth-grade female students in Australia, it was found that there was a significant relationship between the development of students' critical thinking skills and an ICT-enriched environment. In addition, an increase was observed in the critical thinking scores of the students with better computer programming skills (Lazarowitz \& Huppert, 1993; Yalman \& Tunga 2014). Luu and Freeman (2011) reported that entertaining software programs had a negative relationship with scientific literacy. Akyol and colleagues (2010) pointed out that among Turkish elementary schools students, those who had a computer with access to the Internet had lower achievement scores in science. In their study based on the data collected from American and Korean secondary school students within the scope of TIMSS (Trends in Mathematics and Science Studies) in 2003, Won and Han (2010) found a negative relationship in the school success of the students playing computer games considering both the educational backgrounds of the participants' parents and the total number of books available at home. Taking the students' high school placement exam scores into account, Chen and Fu (2009) examined the effects of the students' ICT use and reported that when the students tended to have lower exam scores when they used the Internet to play games and to socialize. Papanastasiou and colleagues (2005) reported that students using computer at school and frequently for programming had lower achievement scores in science. All these studies revealed that ICT use subjects in the fields of science and mathematics were likely to have a relationship with achievement and that secondary school students' critical thinking skills were developed. Kubiatko and Vlckova (2010), in their study with high school students in Check Republic, found a positive relationship between science and ICT aptitude test, while Luu and Freemen (2011) reported that navigation on the Internet had a positive relationship with scientific literacy. Similarly, Chen and $\mathrm{Fu}$ (2009) pointed out that eight-grade students using online search in Taiwan achieved better results in high school placement tests.

Today, educational use of ICTs, now dominating all parts of our lives in the $21^{\text {st }}$ century, is inevitable. It is seen that there are many studies carried out with students from the fields of Science and Mathematics to determine their ICT use and their attitudes towards ICT; however, there is not much research conducted to determine university students' ICT use and their related attitudes in social fields. It is important for students attending the Distant Undergraduate Education Completion Program in Theology (DUECPT) to take education in a way to make better use of ICTs. This is necessary for students to attend their lessons effectively both individually and as a group via the Internet. In general, ICT efficacies in the learning environments of DUECPT students could allow more effective and productive use of the learning processes. However, as in all subjects related to education, various problems and deficiencies are likely to be encountered regarding the ICT efficacies of DUECPT students. Evaluating ICT use levels and related attitudes of especially DUECPT students and overcoming the problems, if any, could increase the quality of education in this field. Considering this thought, the present study examined not only the changes in ICT efficacies of DUECPT students who would use ICT actively and who took their courses with distant education management system via the Internet but also the extent to which they made use of ICTs.

\section{Hypotheses}

What are the DUECPT students' levels of information and communication technology skills?

1. What are the distributions of the students with respect to such factors influential on the students' levels of ICT skills as gender, foreign language proficiency level, computer use experience, Internet use frequency, method of learning, method of studying, way of learning, preferences of mobile device use and motivation type?

2. What are university students' levels of information and communication technology skills?

3. Do students' ICT skills differ significantly with respect to their 
a) Gender

b) Foreign language proficiency

c) Computer use experience

d) Internet use frequency

e) Preferences of studying

f) Preferences of learning

g) Preferences of mobile device use

\section{Method}

The study was designed with the descriptive method to determine the students' levels of information and communication technology skills with respect to certain variables. For the analysis of the research data, the singular and relational survey model, one of general survey models, was used (Karasar, 2012: 77).

\subsection{Data Collection Tools}

The data were collected with the "ICT Skills Scale" developed by Haznedar (2012). The questionnaire was made up of four parts. The first part included 12 items regarding the demographic backgrounds of the students; the second part included 15 items regarding information technologies; the third part included eight items regarding communication technologies; and the last part included five items regarding mobile technologies.

\subsection{Analysis of Data}

For the analysis of the data collected via the questionnaire applied to the distant education students, SPSS. 15.0 package software was used. The items related to ICT skills in the questionnaire were scored as "1" for "I Completely Disagree", "2" for "I Disagree", “3" for "I Partly Disagree", "4" for "I Agree" and "5" for "I Completely Agree”. While interpreting the mean scores regarding the students' attitudes, the values ranging between 1,00-1,80 were regarded as "I Completely Disagree", those between 1,81-2,60 as "I Disagree", those between 2,61-3,40 as "I Partly Agree", those between 3,41-4,20 as "I Agree", and those between 4,21-5,00 as "I Completely Agree". The lowest score to be assigned was 1 , and the highest was 5 . For the analysis of the research data, mean scores, frequencies and percentages were used. Based on the results obtained, the Cronbach Alpha reliability coefficient was calculated as 0,918.

\subsection{Research Sample}

The study was carried out with students attending the Distant Undergraduate Education Completion Program in Theology (DUECPT) in Dicle University in Turkey in the Spring Term of the academic year of 2013-2014. In the study, the "simple random sampling" method, one of probable sampling methods, was applied. In simple random sampling method, each member of a study group has an equal chance of being selected. The research sample to participate in the study was selected from a list of students on random basis (Çepni, 2010: 46). The research sample included 381 students taking distant education in the department of DUECPT.

Table 1 presents information about the gender of the students participating in the study.

Table 1. Frequency Distributions of the participants with respect to their gender

\begin{tabular}{lll}
\hline 'Gender' & $\mathbf{f}$ & $\boldsymbol{\%}$ \\
\hline Female & 152 & 39,9 \\
Male & 229 & 60,1 \\
\hline Total & 381 & 100
\end{tabular}

According to Table 1, of all the students attending the department of DUECPT in Dicle University, 152 of them were female $(39,9 \%)$, and 229 of them were male $(60,1 \%)$.

\section{Findings}

In this section, the results obtained via the analysis of the research data are presented in Tables. Table 2 below demonstrates the Internet-computer attitude mean score of the students.

Table 2. Students' levels of satisfaction with Information and communication technology skills

\begin{tabular}{llll}
\hline & $\mathbf{N}$ & $\overline{\mathbf{X}}$ & Sd \\
\hline Mean & 381 & 3,25 & 0,46 \\
\hline
\end{tabular}


The students' mean score regarding their attitudes towards the Internet and computer was calculated as $\overline{\mathrm{X}}=3,25$.

Table 3. t-test results regarding the students' information and communication technology skills with respect to their gender

\begin{tabular}{lllllll}
\hline Gender & $\mathbf{n}$ & $\mathbf{X}$ & Ss & Sd & t & p \\
\hline Male & 229 & 3,36 & 0,97 & 379 & 2,587 & \multirow{2}{*}{010} \\
Female & 152 & 3,10 & 0,94 & & &
\end{tabular}

According to the research findings, the mean score of the female students was Mean ${ }_{\mathrm{F}}=3,10(\mathrm{Ss}=0,94)$, that of the male students was $\mathrm{Mean}_{\mathrm{M}}=3,36(\mathrm{Ss}=0,97)$. The statistical analysis regarding the mean scores revealed a significant difference between the students' mean scores with respect to gender $\left(\mathrm{t}_{(379)}=2,587 ; \mathrm{p}>.05\right)$. Thus, the male students had better information and communication technology skills than the female students did.

In order to determine whether there was a significant difference between the information and communication technology skills of the students with respect to their preference of learning methods, ANOVA was conducted. The results obtained can be seen in Table 4 .

Table 4. ANOVA results regarding the information and communication technology skills of the students with respect to their preferences of learning method

\begin{tabular}{lllllc}
\hline & $\begin{array}{l}\text { Sum } \\
\text { of Squares }\end{array}$ & Sd & $\begin{array}{l}\text { Mean } \\
\text { of Squares }\end{array}$ & F & $\begin{array}{c}\text { Level of } \\
\text { Significance }\end{array}$ \\
\hline Between Groups & 2,729 & 2 & 1,364 & 1,459 &, 234 \\
Within Groups & 353,620 & 378 &, 936 & & \\
Total & 356,349 & 380 & & & \\
\hline
\end{tabular}

Statistically, no significant difference was found between the information and communication technology skills of the students with respect to their preferences of learning method (Face-to-face education, Face-to-face education + E-learning (Blended Learning) and E-learning) $\left(\mathrm{F}_{2-378}=, 1,459 ; \mathrm{p}=, 234\right)$.

For the purpose of determining whether there was a significant difference between the information and communication technology skills of the students with respect to their weekly Internet use time, ANOVA was conducted.

Table 5. ANOVA results regarding the students' information and communication technology skills with respect to their weekly Internet use time

\begin{tabular}{lllllc}
\hline & $\begin{array}{l}\text { Sum } \\
\text { of Squares }\end{array}$ & Sd & $\begin{array}{l}\text { Mean } \\
\text { of Squares }\end{array}$ & F & $\begin{array}{c}\text { Level of } \\
\text { Significance }\end{array}$ \\
\hline Between Groups & 32,674 & 3 & 3 & 12,686 &, 000 \\
Within Groups & 323,674 & 377 & 377 & & \\
Total & 356,349 & 380 & & &
\end{tabular}

In the study, a statistically significant difference was found between the information and communication technology skills of the students with respect to their weekly Internet use time $\left(\mathrm{F}_{3-377}=12,686 ; \mathrm{p}=, 000\right)$.

Table 6. Tukey HSD Significance test results with respect to the students' weekly Internet use time

\begin{tabular}{llll}
\hline Internet Use Time & & $\begin{array}{l}\text { Mean } \\
\text { Difference }\end{array}$ & $\begin{array}{l}\text { Mean } \\
\text { Difference }\end{array}$ \\
\hline 0-7 hours & 8-21 hours &,- 57787 &, 000 \\
$0-7$ hours & 22-35 hours &,- 75218 &, 002 \\
$0-7$ hours & 36 hours or longer &,- 69180 &, 034 \\
\hline
\end{tabular}

Regarding the students' weekly Internet use time, the results of Tukey HSD test revealed significant differences between the groups of "0-7 hours" and "8-21 hours" in favor of the latter group; between the groups of " $0-7$ hours" and "22-35 hours" in favor of the latter group; and between the groups of " $0-7$ hours" and "36 hours or longer" in favor of the latter group.

In order to determine whether there was a significant difference between the information and communication technology skills of the students with respect to their years of experience in computer use, ANOVA was conducted. 
Table 7. ANOVA results regarding the students' information and communication technology skills with respect to their years of experience in computer use

\begin{tabular}{llllll}
\hline & $\begin{array}{l}\text { Sum } \\
\text { of Squares }\end{array}$ & Sd & $\begin{array}{l}\text { Mean } \\
\text { of Squares }\end{array}$ & F & Level of Significance \\
\hline Between Groups & 65,823 & 4 & 16,456 & 21,297 &, 000 \\
Within Groups & 290,525 & 376 &, 773 & & \\
Total & 356,349 & 380 & & & \\
\hline
\end{tabular}

A statistically significant difference was found between the information and communication technology skills of the students with respect to their years of experience in computer use $\left(\mathrm{F}_{4-376}=21,297 ; \mathrm{p}=, 000\right)$. Table 8 presents the results of Tukey HSD test.

Table 8. Tukey HSD test results regarding the students' years of experience in computer use

\begin{tabular}{llll}
\hline Knowledge of Internet Technology Use & $\begin{array}{l}\text { Mean } \\
\text { Difference }\end{array}$ & $\begin{array}{l}\text { Mean } \\
\text { Difference }\end{array}$ \\
\hline Shorter than 1 year & 4-5 Years &,- 84504 &, 001 \\
Shorter than 1 year & 6-7 Years &,- 87411 &, 000 \\
Shorter than 1 year & Longer than 7 years & $-1,39924$ &, 000 \\
1-3 Years & Longer than 7 years &,- 87364 &, 000 \\
4-5 Years & Longer than 7 years &,- 55420 &, 000 \\
6-7 Years & More than 7 years &,- 52514 &, 001 \\
\hline
\end{tabular}

Regarding the students' years of experience in computer use, results of Tukey HSD test revealed significant differences between the groups of "Shorter than 1 year" and "4-5 years" in favor of the latter group; between the groups of "Shorter than 1 year" and "6-7 years" in favor of the latter group; between the groups of "Shorter than 1 year" and "Longer than 7 years" in favor of the latter group; between the groups of "1-3 years" and "Longer than 7 years" in favor of the latter group; between the groups of "4-5 years" and "Longer than 7 years" in favor of the latter group; and between the groups of "6-7 years" and "Longer than 7 years" in favor of the latter group.

In order to determine whether there was a significant difference between the information and communication technology skills of the students with respect to their foreign languages, ANOVA was conducted.

Table 9. T-test results regarding the students' information and communication technology skills with respect to their foreign languages

\begin{tabular}{lllllll}
\hline foreign language & $\mathbf{n}$ & $\mathbf{X}$ & Ss & Sd & t & p \\
\hline Arabic & 189 & 3,34 & 0,93 & 379 & 1,74 &, 082 \\
English & 192 & 3,17 & 0,99 & & &
\end{tabular}

Regarding their information and communication technology skills with respect to their foreign languages, the mean score of the students who spoke Arabic as a foreign language was $\mathrm{Mean}_{\mathrm{A}}=3,34(\mathrm{Ss}=0,93)$, and the mean score of those who spoke English as a foreign language was $\operatorname{Mean}_{E}=3,17(\mathrm{Ss}=0,99)$. The statistical analysis conducted for the mean scores did not reveal any significant difference between the students' mean scores with respect to their foreign language $\left(\mathrm{t}_{(379)}=1,74 ; \mathrm{p}>.05\right)$.

Table 10 presents the results of the test results conducted to determine whether there was a significant difference between the information and communication technology skills of the students with respect to their levels of proficiency in their foreign language.

Table 10. ANOVA results regarding the students' information and communication technology skills with respect to their levels of proficiency in their foreign language

\begin{tabular}{lllllc}
\hline & $\begin{array}{l}\text { Sum } \\
\text { of Squares }\end{array}$ & Sd & $\begin{array}{l}\text { Mean } \\
\text { of Squares }\end{array}$ & F & $\begin{array}{c}\text { Level of } \\
\text { Significance }\end{array}$ \\
\hline Between Groups & 3,431 & 2 & 1,715 & 1,831 &, 162 \\
Within Groups & 350,300 & 374 &, 937 & & \\
Total & 353,731 & 376 & & &
\end{tabular}

No statistically significant difference was found between the information and communication technology skills of the students with respect to their levels of proficiency in their foreign language $\left(\mathrm{F}_{2-374}=1,831 ; \mathrm{p}=, 162\right)$.

For the purpose of determining whether there was a significant difference between the information and communication technology skills of the students with respect to their preferences of method of learning, $t$ test was conducted. 
Table 11. T-test results regarding the information and communication technology skills of the students with respect to their preferences of method of learning

\begin{tabular}{lllllll}
\hline Preferences of studying & $\mathbf{n}$ & $\mathbf{X}$ & Ss & Sd & t & p \\
\hline Individual & 188 & 3,22 & 0,97 & \multirow{2}{*}{379} &,- 712 & \multirow{2}{*}{477} \\
Group & 193 & 3,29 & 0,96 & & &
\end{tabular}

Regarding their information and communication technology skills, the mean score for the students who preferred individual learning was $\mathrm{Mean}_{\mathrm{I}}=3,22(\mathrm{Ss}=0,97)$, and the mean score for those who preferred group learning was Mean $_{\mathrm{G}}=3,29(\mathrm{Ss}=0,96)$. The results of the statistical analysis conducted regarding the mean scores revealed no significant difference in the students' information and communication technology skills with respect to their preference of method of learning $\left(\mathrm{t}_{(379)}=-, 712 ; \mathrm{p}>.05\right)$.

Table 12 presents the results of t-test conducted to determine whether there was a significant difference between the information and communication technology skills of the students with respect to their motivations for learning (extrinsic motivation or intrinsic motivation).

Table 12. T-test results regarding the students' information and communication technology skills with respect to their motivations for learning

\begin{tabular}{lllllll}
\hline Motivation for Learning & $\mathbf{n}$ & $\mathbf{X}$ & Ss & Sd & t & p \\
\hline Extrinsic & 131 & 3,26 & 0,98 & \multirow{2}{*}{379} & \multirow{2}{*}{000} & \multirow{2}{*}{000} \\
Intrinsic & 250 & 3,26 & 0,96 & &
\end{tabular}

Regarding their information and communication technology skills, the mean score of the students who preferred extrinsic learning was $\mathrm{Mean}_{\mathrm{E}}=3,26(\mathrm{Ss}=0,98)$, and the mean score of those who preferred intrinsic learning was $\left(\mathrm{Mean}_{\mathrm{I}}=3,26, \mathrm{Ss}=0,96\right)$. The results of the statistical analysis conducted regarding the mean scores did not reveal any significant difference in the students' information and communication technology skills with respect to their preferences of way of motivation $\left(\mathrm{t}_{(379)}=, 000, \mathrm{p}>.05\right)$.

In order to determine whether there was a significant difference between the information and communication skills of the students with respect to their preferences of mobile device use, ANAVO was conducted.

Table 13. Results of ANOVA regarding the students' preferences of mobile device use with respect to information and communication technology skills

\begin{tabular}{lllllc}
\hline & $\begin{array}{l}\text { Sum } \\
\text { of Squares }\end{array}$ & Sd & $\begin{array}{l}\text { Mean } \\
\text { of Squares }\end{array}$ & F & Level of Significance \\
\hline Between Groups & 25,984 & 3 & 8,661 & 9,884 &, 000 \\
Within Groups & 330,364 & 377 &, 876 & & \\
Total & 356,349 & 380 & & & \\
\hline
\end{tabular}

A statistically significant difference was found between the information and communication technology skills of the students with respect to their preferences of mobile device use $\left(F_{3-377}=9,884 ; p=, 000\right)$. Table 14 presents the results of the related Tukey HSD test.

Table 14. Results of Tukey HSD test with respect to the students' preferences of mobile device use

\begin{tabular}{|c|c|c|c|c|c|}
\hline \multicolumn{4}{|c|}{ Knowledge of Internet Technology Use } & \multirow{2}{*}{$\begin{array}{l}\text { Mean Difference } \\
, 63473\end{array}$} & \multirow{2}{*}{$\begin{array}{l}\text { Mean Difference } \\
, 000\end{array}$} \\
\hline Smart Phone and Tablet PC & Mobile Phone & & & & \\
\hline Mobile Phone & $\begin{array}{l}\text { Mobile Phone } \\
\text { Computer }\end{array}$ & & Laptop &,- 37934 & 012 \\
\hline Mobile Phone & All & & &,- 73980 & 000 \\
\hline
\end{tabular}

Regarding the students' preferences of mobile device use, the results of Tukey HSD test revealed significant differences between the groups of "Smart Phone and Tablet PC" and "Mobile Phone" in favor of the former group; between the groups of "Mobile Phone" and "Mobile Phone and Laptop Computer" in favor of the latter group; and between the groups of "Mobile Phone" and "All" in favor of the latter group.

\section{Discussion and Conclusion}

The present study aimed at examining the attitudes of the Distant Undergraduate Education Completion Program in Theology (DUECPT) towards information and communication technologies with respect to certain variables. The participants regarding their attitudes towards information and communication technologies had a 'moderate' level of mean score $(X=3,25)$. 
In the study, it was found in terms of gender that the male students had higher levels of computer and communication technology skills when compared to the female students. The findings obtained were similar to those obtained in other studies (Aypay, 2010; Taylor, Goede \& Steyn, 2011; Haznedar, 2012; Tella \& Mutula, 2008; Usluel, 2007; Birgin, Çoker \& Çatlıoğlu, 2010). On the other hand, in one study investigating preservice teachers' attitudes towards online education, Özdemir (2010) reported that there was no significant difference for 496 undergraduate students with respect to their gender. In several other studies carried out with undergraduate students also revealed similar results. In a study conducted by Haznedar (2012) to examine e-learning and undergraduate students' information and communication technology skills, the researcher reported significant differences between the participants' information and communication technology skills and their gender, class grade, proficiency in foreign language, experience in computer use and frequency of Internet use. Verhoeven and colleagues (2014), in their research on undergraduate students' ICT use and their related skills, focused on such variables as gender, field of education, their parents' educational backgrounds and whether they received ICT lessons during their secondary or university education. The researchers reported that there was a significant difference with respect to the students' gender in favor of the male students who took ICT courses previously and whose parents had higher levels of educational background.

In the study, no statistically significant difference was found between the students' information and communication technology skills with respect to their preference of "Face-to-Face Education", "Face-to-Face Education + E-Learning (Blended Learning)" and "E-Learning". The fact that the students did not choose any learning method demonstrates that they adopted more than one learning environment. In one study carried out to determine university students' attitudes towards e-learning, Yalman (2013) found that 58,29\% of the participants were willing to take courses both with face-to-face method of learning and with the distant learning management system. In addition, it was seen that the faculty members preferred both face-to-face education and distant education and that they were thus more prolific (Orhan et.al., 2004; Karaman, 2007).

In the study, it was found that with respect to frequency of Internet use and years of experience in computer use, the university students' ICT skills developed as their years of experience in computer use, their ICT use purposes and their frequency of Internet use increased. In one study conducted with university students, Usluel (2007) reported that the students' perceptions of information literacy self-efficacy increased in line with the increase in their ICT use time. This was an expected result because the students developed their ICT skills by using the Internet and computer. Dinçer and Şahinkayası (2011), in their study carried out with 440 university students in Turkey and Check Republic, examined their levels of satisfaction with ICT and found that $89,01 \%$ of the participants were computer-literate. In another study on information literacy, Gross and Latham (2007) found that 55\% of the students had a medium level and advanced level of information literacy. In related literature, there are a number of studies conducted to reveal teachers' ICT skills. In one study, Albirini (2006) reported that $43,3 \%$ of the teachers did not have any computer skills; that $39,5 \%$ of them had a lower level of computer skills; that $16,6 \%$ of them had a moderate level of computer skills; that $0,6 \%$ of them had good levels of computer skills; and that the participants' levels of computer skills were $\bar{X}=1,78$ out of four. Konan (2010) found that teachers had a moderate level of computer literacy $(\bar{X}=3,03)$. In another study carried out with 270 teachers, Altun (2007) reported that the teachers had a mean score of $\bar{X}=2.63$ regarding their computer use skills. Considering the skills that teachers are expected to have in the field of ICTs, Cüre and Özdener (2008) examined teachers' practical successes in information and communication technologies and found that the ICT teachers had a mean score of $\bar{X}=42,2$ out of 63 regarding their general practical successes. Tasir and colleagues (2012) conducted a study with 184 teachers and M.A. students and found that the teachers' ICT efficacies were found to be $\bar{X}=3,95$. When studies regarding ICT uses of the teachers and of the university students were examined, it was seen that the university students had high levels of mean scores regarding their attitudes towards ICT.

In the study, no statistically significant difference was found between the information and communication technology skills of the students with respect to their foreign languages. On the other hand, Özdemir (2010) points out that the effects of foreign language on individuals' levels of information technology skills are important. Although level of proficiency in foreign language does not have a direct relationship with information and communication technology skills, the distinct difference regarding ICT skills between the students with different levels of proficiency in foreign language could be thought to result from the fact that computer terms and computer programs mostly require a foreign language.

In the study, no significant difference was found between the participants' preferences of learning individually or in a group.

The results also revealed a significant difference between the information and communication technology skills of the participants with respect to mobile communication devices and portable computer use. It was seen that the participants' ICT skills differed depending on their use of more than one mobile device (mobile phone, laptop computer, Tablet PC, smart phone). Among the participants in the study, there was a significant difference in ICT skills of those in the group 
who preferred only mobile phone when compared to other groups. This situation could explain the fact that the students did not master computer and Internet environments efficiently. In one study carried out with preservice teachers, Yurdakul (2011) examined the technopedagogical efficacy of preservice teachers with respect to their use of information and communication technologies and found that $1,2 \%$ of the preservice teachers had a low level of information and communication technology use; that $45 \%$ of them had a moderate level; and that $52,8 \%$ of them had a high level of information and communication technology use. Usta and Korkmaz (2010), in their study conducted with 106 preservice teachers, reported that $24,6 \%$ of them believed they were novice in terms of their computer skills; that $39,6 \%$ of them believed they had a moderate level of computer skills; and that $35,8 \%$ of them believed they were advanced in computer skills. Accordingly, approximately $25 \%$ of the preservice teachers did not have efficient computer skills, while $75 \%$ of them could be said to have efficient computer skills. In another study, Özdemir, Akbaş and Çakır (2009) reported that the information literacy skills of 235 preservice teachers were at a high level $(\bar{X}=3,95$ out of five). Although there is apparently much research on teachers' ICT skills and on their ICT use, there is still on-going related interest in different professional fields. In one study carried out to examine lawyers' ICT use, Kılıç (2009) reported that $97 \%$ of them made use of the computer in their job and that 57\% of them used the computer without having any related training previously on computer use. Hsu, Hou, Chang and Yen (2009) carried out a study with 203 nurses to examine their levels of computer literacy and found that the participants had a moderate level of computer literacy $(\bar{X}=3,15$ out of five). Considering the fact that information and communication technologies are now widespread in all fields, information and communications technology skills are fairly important for all individuals from any professional group. Therefore, it is necessary to combine these skills with life-long learning during individuals' undergraduate education. In this way, besides vocational education in higher education, a high level of ICT skills and a high level of ICT use in professional life will lead to individuals trained on the basis of life-long self-learning. In their study, Tuparova and Tuparov (2010) views this subject from a different perspective and points out that it is necessary to determine individuals' ICT skills and that what is more important is to determine which type of skills will be evaluated and which methods will be used for such a purpose.

Studies like this could lead to other different studies to be conducted examine the current related situation and to help teachers and students gain ICT skills, which are quite important. In the present study, the purpose was to determine university students' information and communication technology skills and to contribute to higher education as well as to future related studies.

\section{References}

Akyol, G., Sungur, S., \& Tekkaya, C. (2010). The contribution of cognitive and metacognitive strategy use to students' science achievement. Educational Research and Evaluation. http://dx.doi.org/10.1080/1380361100367234816

Albirini, A. (2006). Teachers' attitudes toward information and communication technologies: the case of Syrian EFL teachers. Computers \& Education, 47(4), 373-398. http://dx.doi.org/10.1016/j.compedu.2004.10.013

Altun, S. (2007). İlköğretim Okullarında Çalışan Öğretmenlerin Bilgisayar Kullanma Becerileri ve Bilgisayar Destekli Öğretime İlişkin Tutumları Üzerine Bir Araştırma(Bartın İli Örneği). (Yayımlanmamış Yüksek Lisans Tezi) Gazi Üniversitesi, Eğitim Bilimleri Enstitüsü, Ankara.

Aypay, A. (2010). Information and communication technology usage and achivement of Turkish students in Pisa 2006. The Turkish Online Journal of Educational Technology-TOJET, 9(2), 116-124.

Birgin, O., Çoker, B., \& Çatlıoğlu, H. (2010). Investigation of first year pre-service teachers' computer and internet uses in terms of gender. Procedia Social and Behavioral Sciences, 2(2), 1588-1592. http://dx.doi.org/10.1016/j.sbspro.2010.03.241

Carlsson, C., Carlsson, J., Hyvönen, K., Puhaikanen, P., \& Walden, P. (2006). Adoption of Mobile Devices/Services-Searching for Answers with the UTAUT. Proceedings of the 39th Hawai International Conference on system sciences.

http://www2.computer.org/plugins/dl/pdf/proceedings/hicss/2006/2507/06/250760132a.pdf?template=1\&loginStat $\mathrm{e}=1$ \&userData=anonymous-IP $\% 253 \mathrm{~A} \% 253 \mathrm{~A} 127.0 .0 .1$ )

Çepni, S. (2010). Araştırma ve Proje Çalışmalarına Giriş, 5.Baskı, Celepler Matbaacılık, Trabzon.

Chatzoglou, P. D., Sarigiannidis, L., Vraimaki, E., \& Diamantidis, A. (2009). Investigating Greek employees' intention to use web-based training. Computers \& Education. http://dx.doi.org/10.1016/j.compedu.2009.05.007

Chen, S. Y., \& Fu, Y. C. (2009). Internet use and academic achievement: gender differences in early adolescence. Adolescence, 44(176), 797-842.

Cho, V., Cheng, T. C., \& Lai, W. M. (2009). The role of perceived user-interface design in continued usage intention of self-paced e-learning tools. Computers \& Education. http://dx.doi.org/10.1016/j.compedu.2009.01.014 
Cüre, F., \& Özdener, N. (2008). Öğretmenlerin bilgi ve iletişim teknolojileri (BİT) uygulama başarıları ve BİT’e yönelik tutumları. Hacettepe Üniversitesi Ĕ̆itim Fakültesi Dergisi, 34, 41-53.

Dinçer, S., \& Şahinkayası, Y. (2011). A cross-cultural study of ICT competency, attitude and satisfactıon of Turkish, Polish and Czech university students. The Turkish Online Journal of Educational Technology - TOJET, 10(4), 31-38.

Frrat, E. A., \& Özden, M. (2013). İLKÖĞRETIM ÖĞRENCILLERININ BILGGI İLETIŞiM TEKNOLOJiLERINDEN YARARLANMA DÜZEYLERİ VE BİLIMSEL SÜREÇ BECERILERİ ARASINDAKİ İLIŞKİ. Adlyaman Üniversitesi Sosyal Bilimler Enstitüsü Dergisi, 2013(15).

Gross, M., \& Latham, D. (2007). Attaining information literacy: An investigation of the relationship between skill level, self estimates of skill and library anxiety. Library \& Information Science Research, 29, 332-353. http://dx.doi.org/10.1016/j.lisr.2007.04.012

Hargittai, E. (2010). Digital na(t)ives. Variation in Internet skills and uses among members of the "Net Generation". Sociological Inquiry. http://dx.doi.org/10.1111/j.1475-682X.2009.00317.x

Haznedar, Ö (2012). Üniversite Öğrencilerinin Bilgi Ve İletişim Teknolojileri Becerilerinin Ve E-Öğrenmeye Yönelik Tutumlarının Farklı Değişkenler Açısından İncelenmesi. (Yayınlanmış yüksek lisans tezi). Dokuz Eylül Üniversitesi, Eğitim Bilimleri Enstitüsü, İzmir.

Hsu, H. M., Hou, Y. H., Chang, C., \& Yen, D. C. (2009). Factors influencing computer literacy of Taiwan and South Korea nurses. J. Med. Syst., 33, 133-139. http://dx.doi.org/10.1007/s10916-008-9173-5

Kaminski, K., Switzer, J., \& Gloeckner, G. (2009). Workforce readiness: a study of university students' fluency with information technology. Computers \& Education. http://dx.doi.org/10.1016/j.compedu.2009.01.017

Karaman, S. (2007). Ders Web Sayfaları: Özellikleri, Hazırlanması, Kullanılması ve Öğretim Elemanlarının Tutumu, İönü Üniversitesi Eğitim Fakültesi Dergisi, 7(13), 47-68.

Karasar, N. (2012). Bilimsel araştırma yöntemi. Ankara: Nobel Yayınları.

Kılıç, S. (2009). Avukatların bilgi ve iletişim teknolojilerini kullanma durumlarının ve e-öğrenmeye yönelik görüşlerinin belirlenmesi. (Yayınlanmamış yüksek lisans tezi). Bahçeşehir Üniversitesi, Fen Bilimleri Enstitüsü, İstanbul.

Konan, N. (2010). Computer literacy levels of teachers. Procedia Social and Behavioral Sciences, 2, 2567-2571. http://dx.doi.org/10.1016/j.sbspro.2010.03.374

Kubiatko, M., \& Vlckova, K. (2010). The relationship between ICT use and science knowledge for Czech students: a secondary analysis of PISA. International Journal of Science and Mathematics Education, 8(3), 523-543. http://dx.doi.org/10.1007/s10763-010-9195-6

Kutluca, T. (2010). Investigation of teachers' computer usage profiles and attitudes toward computers. International Online Journal of Educational Sciences, 2(1), 81-97.

Lazarowitz, R., \& Huppert, J. (1993). Science Process Skills of 10th-Grade Biology Students In a Computer-Assisted Learning Setting, Journal of Research on Computing in Education, 25(3), 367-382. http://dx.doi.org/10.1080/08886504.1993.10782057

Lee, B. C., Yoon, J. O., \& Lee, I. (2009). Learners' Acceptance of e-learning in South Korea: theories and results. Computers \& Education. http://dx.doi.org/10.1016/j.compedu.2009.06.014

Lee, M. C. (2010). Explaining and predicting users' continuance intention toward e-learning: an extension of the expectation-confirmation model. Computers \& Education. http://dx.doi.org/10.1016/j.compedu.2009.09.002

Lee, Y. C. (2008). The role of perceived resources in online learning adoption. Computers \& Education. http://dx.doi.org/10.1016/j.compedu.2007.01.001

Luu, K., \& Freeman, J. G. (2011). An analysis of the relationship between information and communication technology (ICT) and scientific literacy in Canada and Australia. Computers \& Education. http://dx.doi.org/10.1016/j.compedu.2010.11.008

McMahon, G. (2009). Critical thinking and ICT integration in a Western Australian secondary school. Educational Technology \& Society, 12(4), 269-281.

Orhan, F., Altun, A. S., \& Kablan, Z. (2004). Karma Ögrenme (Blended Learning) Yöntemine Dayalı Bir Uygulama ve Ögrenci Görüsleri: Yıldız Teknik Üniversitesi Örnegi, IV. Uluslararası Egitim Teknolojileri Sempozyumu, 24-26 Kasım 2004, Sakarya, Türkiye

Özdemir, L. (2010). BILLIŞiM TEKNOLOJISI TUTUMLARI FARKLI ÜNIVERSITE PERSONELININ BILLIŞIM TEKNOLOJISI BECERILERINIIN DEĞERLENDİRILMESİ. Atatürk Üniversitesi İktisadi ve İdari Bilimler Dergisi, 24(1). 
Özdemir, S. M., Akbaş, O., \& Çakır, R. (2009). A study on the relationship between pre-service teachers' information literacy skills and their attitudes towards distance education. Procedia Social and Behavioral Sciences, 1, 1648-1652. http://dx.doi.org/10.1016/j.sbspro.2009.01.291

Papanastasiou, E. C., Zembylas, M., \& Vrasidas, C. (2005). An examination of the Pisa Database to explore the relationship between computer use and science achievement. Educational Research and Evaluation. http://dx.doi.org/10.1080/13803610500254824

Peter, J., \& Valkenburg, P. M. (2006). Adolescents' internet use: Testing the "disappearing digital divide" versus the "emerging digital differentiation" approach. Poetics, 34(4), 293-305. http://dx.doi.org/10.1016/j.poetic.2006.05.005

Salajan, F. D., Schönwetter, D. J., \& Cleghorn, B. M. (2010). Student and faculty inter-generational digital divide: fact or fiction. Computers \& Education. http://dx.doi.org/10.1046/j.1365-2923.2004.01786.x

Strøms $\varnothing$, H. I., Grottum, P., \& Lycke, K. H. (2004). Changes in student approaches to learning with the introduction of computer-supported problem-based learning. Medical Education. http://dx.doi.org/10.1046/j.1365-2923.2004.01786.x

Tasir, Z., Abour, K. M., Halim, N. D., \& Harun, J. (2012). Relationship between teachers' ICT competency, confidence level, and satisfaction toward ICT training programmes: a case study among postgraduate students. The Turkish Online Journal of Educational Technology -TOJET, 11(1), 138-144.

Taylor, E., Goede, R., \& Steyn, T. (2011). Reshaping computer literacy teaching in higher education: Identification of critical success factors. Interactive Technology and Smart Education, 8(1), 28-38. http://dx.doi.org/10.1108/17415651111125496

Tella, A., \& Mutula, S. M. (2008). Gender differences in computer literacy among undergraduate students at the university of Botswana: implications for library use. Malaysian Journal of Library \& Information Science, 13(1), 59-76.

Teo, T., Lee, C. B., Chai, C. S., \& Wong, S. L. (2009). Assessing the intention to use technology among preservice teachers in Singapore and Malaysia: a multigroup invariance analysis of the Technology Acceptance Model (TAM). Computers \& Education. http://dx.doi.org/10.1016/j.compedu.2009.05.017

Tuparova, D., \& Tuparov, G. (2010). Automated real-live performance-based assessment of ICT skills. Procedia Social and Behavioral Sciences, 2, 4747-4751. http://dx.doi.org/10.1016/j.sbspro.2010.03.762

Usluel, Y. K. (2007). Can ICT usage make a difference on student teachers' information literacy self-efficacy. Library \& Information Science Research, 29, 92-102. http://dx.doi.org/10.1016/j.lisr.2007.01.003

Usta, E., \& Korkmaz, Ö. (2010). Öğretmen adaylarının bilgisayar yeterlikleri ve teknoloji kullanımına ilişkin algıları ile öğretmenlik mesleğine yönelik tutumları. Uluslararası Insan Bilimleri Dergisi, 7(1), 1336-1349.

Van Dijk, J. A. (2006). Digital divide research, achievements and shortcomings. Poetics, 34(4), 221-235. http://dx.doi.org/10.1016/j.poetic.2006.05.004

Verhoeven, J, C., Heerwegh, D., \& Wit, K. D. (2014). ICT learning experience and research orientation as predictors of ICTskills and the ICTuse of university students, Educ. Inf. Technol. http://dx.doi.org/10.1007/s10639-014-9310-3

Wang, Y., Wu, M., \& Wang, H. (2009). Investigating the determinants and age and gender differences in the acceptance of mobile learning. British Journal of Educational Technology. http://dx.doi.org/10.1111/j.1467-8535.2007. 00809.x.

Won, S. J., \& Han, S. (2010). Out-of-School activities and achievement among middle school students in the USA and South Korea. Journal of Advanced Academics, 21(4), 628-661. http://dx.doi.org/10.1177/1932202X1002100404

Yalman, M. (2013). Eğitim Fakültesi Öğrencilerinin Bilgisayar Destekli Uzaktan Eğitim Sistemi (Moodle) Memnuniyet Düzeyleri. Electronic Turkish Studies, 8(8). http://dx.doi.org/10.7827/TurkishStudies.5357

Yalman, M., \& Tunga, M. A. (2014). Examining the Attitudes of Students from State and Foundation Universities in Turkey towards the Computer and WWW (World Wide Web). EDUCATION AND SCIENCE, 39(173), 221-233.

Yurdakul, I. K. (2011). Öğretmen adaylarının teknopedagojik eğitim yeterliklerinin bilgi ve iletişim teknolojilerini kullanımları açısından incelenmesi. Hacettepe Üniversitesi Eğitim Fakültesi Dergisi, 40, 397-408.

\section{$(\mathrm{cc}) \mathrm{BY}$}

This work is licensed under a Creative Commons Attribution 3.0 License. 